\title{
Maintaining the connection: experiences of parents and mothers who they have lost their son for
} cancer

\begin{abstract}
Summary
For parents, the death of a child (a) cancer is a big impact and can cause major health problems for a deterioration in their lifestyle. However, some manage to overcome and find a new meaning to his life. Objective: To understand the experiences that help parents to revive after the death of his son (a). Methodology: qualitative study with phenomenological approach, according to Streubert. 8 parents who believe they have developed their grief and participated in the Re-Living Corporation were interviewed. Data were collected through interviews, whose guiding question was: What is the experience that helped him live again after the death of his son (a) to cause cancer? In analyzing the interviews, it revealed the existence of a transition from survival to revival, where one of the key elements was to keep the link with the deceased child through feeling that their children/as always accompany them, dream about them or even experiencing supernatural experiences.
\end{abstract}

Conclusion: The link that keep parents changes direction, where they went from being protectors and caretakers of their children, to be protected and cared for by their children.

Keywords: parents, bereavement, child cancer
Volume 2 Issue 3 - 2018

\author{
Vega Paula V,' Maria Soledad Rivera $M,{ }^{2}$ Rina \\ Gonzalez R' \\ 'Department of Child and Adolescent Health, Pontificia \\ Universidad Catolica de Chile, Chile \\ ${ }^{2}$ Department of Women's Health, Pontifical Catholic University \\ of Chile, Chile
}

Correspondence: Vega Paula V, Department of Child and Adolescent Health, School of Nursing, Pontifical Catholic University of Chile,Vicuña Mackenna 4806, Macul, Santiago, Chile,Email pvegav@uc.cl

Received: April 10, 2018| Published: May 10, 2018

\section{Introduction}

Childhood cancer is the second leading cause of death in children between 5 and 15 years and in Chile, reaches a mortality rate of 2.8 per 100,000 children in $20011 .{ }^{1}$ One factor which has led to these figures is the cooperative work within the National Children's Cancer Program (PINDA), which has led to significant advances in early detection and treatment of this health problem. However, about $25 \%$ of children (as) die for this cause. ${ }^{1}$ The death of a child (a) because of cancer creates a great impact on parents, considering that not only suffer during the disease process to care for and accompany the child (a), but also by the gradual deterioration of health their children (as) and subsequent death. ${ }^{2,3}$ This experience can cause in families stressors, changing its dynamics, especially when there are barriers that do not allow them to accept the absence of his son (a), and are forced to face a new reality. ${ }^{4,5}$ This is reflected in major changes in your lifestyle, increasing alcoholism, smoking and changing your eating patterns, which adds to psychopathological changes, which increases susceptibility to infectious diseases, oncological diseases and mental health. ${ }^{6,7}$

However, there are parents who have managed to overcome this experience and find meaning in his life. Some of them are grouped in Re-Living Corporation, which look welcoming and accompanying parents who experience the loss of a child (a) because of cancer. In this context, it is important to deepen the study of the experience of these parents who have suffered the death of a child (a) because of cancer in Chile and believe they have developed their grief.

\section{Objective}

This study aims to understand the experiences that help parents to revive after the death of his son (a).

\section{Methodology}

Qualitative study of phenomenological design, based on the perspective of Husserl, who emphasizes that it is a "return to the reflexive intuition to describe and clarify the experience as lived and built from the consciousness of the person carrying the phenomenon of interest." ${ }^{1}$ This study was performed following each step of the process described by phenomenological Streubert, ${ }^{9}$ which began performing bracketing by all authors. The sample was for convenience, whose inclusion criteria were to be parents participating in the Corporation reliving the time of the interview, who have lost a child (a) because of cancer over a year ago, they considered have developed their loss, they had authorization from the corporation psychologist (who ensured that the interview did not constitute a risk in its therapeutic process), and who have voluntarily agreed to participate. They were invited to participate through the psychologist of the corporation, they were subsequently contacted by telephone by the author to schedule the interview. It was conducted through in-depth interviews by the same investigator, after signing the informed consent. Asked guided the interview was: Could you share me what experiences helped him live again after the death of his son (a)? Each interview was conducted individually and audio recorded and then be transcribed verbatim. The narratives were subjected to a comprehensive analysis for each of the three authors who, after triangulation, meaning unveiled units, grouping them into larger units and structuring the phenomenon once 
data with the eighth interviews saturated. The revealed phenomenon was confirmed by 3 participants interviewed. a review of the extensive literature is then performed to place the phenomenon revealed. The interviews were conducted from March to October 2009. The study was approved by the Ethics Committee of the School of Nursing at the Pontificia Universidad Catolica de Chile. It is important to note that children's names have been preserved in the narrative at the request of the parents, because it is a way to transcend his memory.

\section{Results}

Participants were three parents and five mothers, 35 to 47 years. When interviewed, they had a time of mourning between 2 to 6 years. All participants were stable partner and had 2 to 3 children. 8 professed the Catholic religion, however, only two of them were practitioners. In relation to their deceased children, children (as) were aged 3 to 8 years old when he died.

\section{Findings}

Parents experience a transition from survival to revival, for which one of the most significant experiences is maintaining a permanent bond with my son (a) dead (Figure 1). For parents, the death of their child (ren) occurs only in a bodily level, since for them the spirit of their children (as) is still alive. They firmly believe their child (ren) maintain an existence as "angels with God," what comforts them and allows them to be connected in a permanent bond with them. That way your children continue to be concretely present in his current life. Moreover, they share with them all the experiences and emotions, such as sadness, fear, guilt, anguish and joys of everyday life in a permanent dialogue. This "special relationship" was born when fired them and then is revealed and strengthened in many situations like feel that their children / as always accompany them, dream about them or even experiencing supernatural experiences. It is these experiences that make them feel they are cared for, comforted, petted and loved by their children (as), creating in them the tranquility and comfort seeking, since pain and suffering refers only to not being able to see them and embrace them, which it is much more encouraging to feel the emptiness of his presence. It is this bond that keeps alive their children (as) in his heart and comforts:

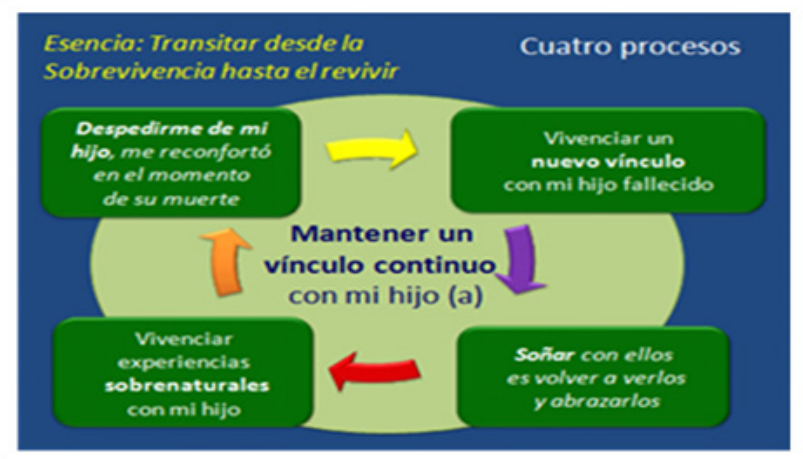

Figure I Maintain a permanent bond with my deceased child

You say goodbye to my son, I comforted at the time of his death.

Bounce, is an experience much pain and suffering for the parents, because it is the time when your child should accept (a) must go. However, they recognize that this moment is liberating for the child (a) and himself. On the other hand, parents who experience the farewell can express all the love you have for your child (a). It is at this moment which often promises to maintain a link beyond death are, giving them hope and faith, which helps them develop loss:

"And the doctor tells me: "Mommy, despídete ... despídete that already have to go" .... I grabbed him, hugged him, still holding his little hand ... and spoke into his ear: "Daddy, I love you, thank you for being my son ... rests !, because it's a lot. I all I ask is that you look after us ... and give me strength to me. I love you, I love you, I love you ... but now go to rest. I love you so much! ... Then I said that ... he breathed his last". (E8) "I think that was even what I find so beautiful, asleep in my arms! That last contact life is here [pointing with hand her heart] ... After I put the mask back ... I look Matthias and changed color and was not breathing and Matthias. And I said, "aunt went peladito" ... But you know, I'm not broke the shot ... but I thought of all ... it's like ideal."'(E1)

\section{The experience of a new bond with your child (a) late (a)}

The death of his son (a) causes a change in the kind of fatherson bond maintained until then. This link changes direction because they spend being protected protectors of their children (as). It is at the moment of departure, when children (as) are parents who prepare to face this devastating experience:

"Because our children are going to die the day that we do not remember them. I assure you that ever going to happen, the dwarves are always present! When will I be paperwork ... "Dwarfs please help me" ... and I have opened a number of doors. First for me, he is my light ... He enlightens me and guide me. Gives me all the energy I have. "(E7)

"My daughter has been the mainstay in my life. Because it gives me energy, strength, desire to live, to continue ... because Hayelen is with me every day She is a living thing that I have! The only bad thing is that I cannot embrace. " $(\mathrm{E} 3)$

\section{Dream about them is to see them and hug}

Dreaming of children (as) has become a need felt by many parents, who see in it the possibility of being able to see them and embrace them, if only in dreams. For them it is a wonderful and unique moment that gives them the peace of mind to confirm that their children (as) are fine, in a beautiful place, and where they live happy:

"Reliving is a mom that her daughter was a friend of Matthias. She died before my child. Matthias died the day my friend dreamed of her daughter.

She told me that her daughter asked him in a dream, why I was $\operatorname{sad}$ ?...

She tells him she was very sad because Matthias had died.

The girl replied: "Yes, I knew, because all the kids got together and went to wait, and went limp Matthias ... no! It was super good, but came angry.

When he arrived next to us, he looked to God and said, "and he, who is he?" Mom! said:? This God "..." What Diosito said, "I asked her:

"God said, Son have a lot of work." (E2)

Experiencing supernatural experiences with my son (a)

Some parents tell supernatural experiences they've had with their 
children (as) deceased, in which they have the firm belief that their children (as) are with them and that way they can communicate. These experiences are unique, encouraging and do not generate fear:

"In fact my son is responsible for sending messages, as in the day of the mother. The daughter of a neighbor wrote me a letter and said, "I got this." It was a letter from Matthew and said, "Mom I'm fine, Matthias"... "Why did you write that?"... "Because Matias told me to write it, and I wrote it." I feel that, somehow, try tell me things ... I know its okay, I know it is looking at me."(E2)

\section{Discussion and conclusions}

During the story of the parents interviewed, they reported being continuously connected with their children (as), saying that this situation generates a great comfort and tranquility against physical loss. However, it is important to note that for the parents the bond begins with the ritual of farewell, given the importance of experiencing the time of death as a natural and healthy reality. ${ }^{10,11}$ While traditional authors insisted that the relatives should "forget" through detachment and redirect emotional energy on other links, contemporary researchers argue that the relatives are linked to the deceased to transform its symbolic connections. Other authors point out that, for parents, children remain immortal in the sense of inner representation, so they remain real in their social world through symbolization of biological and historical ties, feeling the presence of their children, listen to his voice, and feel in touch with them, thus influencing their quality of life. ${ }^{12,13}$ There is even talk of "living in a world without end," considering that this situation allowed them to have an ongoing relationship with his deceased son, becoming a factor in the healing process duel. ${ }^{14-16}$ In the present investigation could reveal that this link was a real phenomenon for parents interviewed, however, they were telling that the link address had changed, and were the parents who now feel protected and cared for their children.

Some authors emphasize that instances of communication at the end of life are very important, especially enjoying the presence of another in an intimate and personal contact, allowing mourners to preserve beautiful memories that gives them greater serenity during the grieving process. ${ }^{17-19}$ This is consistent with the experienced by study participants, who noted that the time of death of children was very special and beautiful as they saw their son (a) was asleep gradually, without pain and suffering, surrounded by people who loved them.

Another way that gives life to the continuity of the link are dreams, which were reported by participants in this investigation. The fact dream of their children became one of the most concrete forms between the bereaved and deceased communication. This is consistent with other studies in which parents claim that through dreams can confirm that their children are well, helping them build an alternative between reality and aspirations. ${ }^{18,20}$ In turn, parents dream that their children are happy, allowing you to de-stress, and continue towards the elaboration of mourning. What may be mediated by culture and spiritual beliefs of parents. ${ }^{21}$

Under this continuous link, there are situations or experiences to which participants were unable to give a coherent and natural explanation. For its supernatural origin, parents have long preferred to save them as a personal and intimate memories, for fear of ridicule or that crazy tildaran. ${ }^{22}$ However, several studies have shown that these experiences are presented in the mourners, who reported manifestations post mortem visions, sensations of a physical presence and other supernatural connections with dead people, creating in them a positive impact on their grief, which for several researchers it can be considered a normal process, which allows parents to give another meaning to their experience of mourning. ${ }^{23-26}$

Therefore, one can conclude that this research allowed us to understand that parents pass from surviving to revive, and in the process maintain a continuous and special bond with your child (a). It could reveal that parents interviewed this link had changed direction, where they went from being protectors and caretakers of their children, to be protected and cared for by their children. From these findings, it is necessary to strengthen the development of mutual support groups and follow-up of the bereaved by a team of health interdisciplinary and specialized in supporting bereaved in each of the oncology units in the country. $11,16,19,27$

\section{Acknowledgements}

The team appreciates the sincerity and trust of each of the parents and parents who participated in the research.

\section{Conflict of interest}

The author declares no conflict of interest.

\section{References}

1. Campbell M. Technical Report MINSAL-PINDA. 2014.

2. Wolfe J, Grier HE, Klar N, et al. Symptoms and suffering to the end of life in children with Cancer. N Engl J Med. 2000;342(5):326333.

3. Kreicbergs U, Valdimarsdóttir U, Onelóv E, et al. Care - Relate distress: a National Study of Parents Who Lost Their child to cancer. J Clin Oncol. 2005;23(36):9162-9171.

4. Arnold J, Buschman P. The Continuing process of parental grief. Death Studies. 2008;32:658-673.

5. Grau C, del Carmen Espada M. Perceptions of parents of children with cancer on changes in family relationships. Psicooncología. 2012;9(1):125-136.

6. Thompson A, Miller K, Barrera M, et al. A qualitative study of advice from parents bereaved and siblings. J Soc Work End Life Palliat Care.2011;7(2-3):153-172.

7. Murphy S, Johnson C, Wu L, et al. Bereaved parents 4 to 6 months outcomes After their children's deaths by accident, suicide, or homicide: a comparative study demonstrating Differences. Death Studies. 2003;27(1):39-61.

8. Husserl E. Ideas concerning pure phenomenology. 3rd ed. Mexico: Cultural Economy Fund; 1947.

9. Streubert H, Carpenter D. Qualitative research in nursing: advancing the humanistic imperative. 4th ed. Philadelphia: Lippincott Williams \& Wilkins; 2007. p.1-501.

10. Fonegra Jaramillo I. Facing death. Coping with sorrow, pain and suffering and death to live fully. Santiago, Chile: Editorial Andres Bello; 2001. 
11. Stevenson M, Achille M, Liben S. et al. Understanding how bereaved cope with their parents to grief inform the services provided to them. Qual Health Res. 2017;27(5):649-664.

12. Aschenbrenner AJ, Winters \& Belknap R. Integrative review: parent perspectives on care of their child at the end of life. $J$ Pediatr Nurs. 2012;27(5):514-522.

13. Silverman P, Klass D. Introduction: What's' the problem. In: Klass D, Silverman \& Nickman PS. Continuing bonds: new understandings of grief. Washington, USA: Taylor \& Francis; 1996:3-23.

14. Klass D. Continuing conversation About Continuing bonds. Death Studies. 2006;30(9):843-858.

15. Talbot K. What means forever after the death of a child: transcending the trauma, living with the loss. Washington, USA: Taylor \& Francis; 2002:296.

16. Björk M, Sundler A, Hallstrom I, et al. Like being covered in a blanket wet and dark - Parents' lived experiences of losing a child to cancer. Eur J Oncol Nurs. 2016;25:40-45.

17. Lynn R. Living in a world without closure: reality for parents who have experienced the death of a child. $J$ Palliat Care. 2006;22(2):75-82.

18. Baker J. Mourning and the transformation of object relationships. Evidence for the persistence of attachments. Psychoanalytic Psychology. 2001;18(1):55-73.

19. Price J, Jordan J, Prior L, et al. Living through the death of a child: a qualitative study of bereaved parents' experiences. Int $J$ Nurs Stud. 2011;48(11):1384-1392
20. Dumont I, Dumont S, Mongeau S. End-of-life care and the grieving process: family caregivers Who Have experienced the loss of a terminal-phase cancer patient. Qual Health Res. 2008;18(8):1049-1061.

21. Klass D, Goss R. Spiritual bonds to the dead Incross cultural and historical perspective: comparative religion and modern grief. Death Studies. 1999;23(6):547-567.

22. Wiener L, Aikin A, Blecher M, et al. Visions of those who left too soon. Am J Nurs. 1996;96(9):57-61.

23. Kubler-Ross E. On childen and death. New York: Collier Books; 1993.

24. Decinque N, Monterosso L, Dadd G, et al. Bereavement Support for families following the death of a child from cancer: practice characteristics of Australian and New Zealand paediatric oncology units. J Paediatr Child Health. 2016;24(2):65-82.

25. Riley L, La Montagne L, Hepwoth J, et al. Parental responses and grief following the death Personal growth of a child. Death Studies. 2007;31(4):277-299.

26. Malinnski V. Dying and grieving seen though a unitary lens. Nurs Sci Q. 2006;19(4):296-297.

27. Neimeyer R, Prigerson H, Davies B. Mournig and meaning. American Behavioral Scientist. 2012;46(2):235-251. 